UDC 639.2.052

DOI https://doi.org/10.32851/2226-0099.2019.110-2.28

\title{
ASSESSMENT OF FISH PRODUCTIVITY OF THE YASKI FISHERY FOR FORMING A SPECIAL COMMERCIAL FISHERY
}

\author{
Soborova O.M. - Candidate of Geographical Sciences, \\ Assistant of Aquatic Bioresources and Aquaculture Department, \\ Odessa State Environment University \\ Burgaz M.I. - Candidate of Biological Sciences, \\ Docent of Aquatic Bioresources and Aquaculture Department, \\ Odessa State Environment University
}

The Odessa region is very rich in various water bodies and according to the natural and climatic conditions of the territory, they all are suitable for fish production.

Commercial fish production on the basis of pond farms of different purposes is a promising area in fish farming. Its value in the agricultural sector of the country is increasing steadily. Modern fisheries in the most small water bodies do not take into account the productive capabilities of these bodies. The gap between the possible and actual fish productivity magnitudes is large enough and reaches one or two orders of magnitude, indicating significant reserves which rational using will improve the fishery efficiency. In this case, the main increase in production can be obtained by optimizing the use of natural feed resources, i.e. using grazing aquaculture.

It is difficult to overestimate the value of the natural feed base for aquaculture. In complex water bodies it is a necessary part of a fish ration, which largely determines a success of fishing.

A pond natural feed base includes a complex of hydrobionts that are used for feeding directly or through intermediate food units and determines increasing in fish products.

In this case, a natural feed base is divided into a potential base, which includes the whole complex of aquatic organisms inhabiting the water body, and a real base, i.e. a part of a potential forage base, which is consumed by a certain fish species at this age stage.

The purpose of the work was to find out the fish productivity of the Yaski fishery in order to create a special commercial fishery.

In this work, the possibility of efficient fishery management and obtaining the commercial fish products in the Yaski fishery and their further sale to the population is proved and the recommendations for the creation of a special commercial fishery are given.

Key words: fisheries, ponds, fish productivity, feed base, fish farming, ichthyofauna.

Соборова О.М., Бургаз М.I. Оцінка рибопродуктивності рибного господарства "Яски" з метою створення спеціального товарного рибного господарства

Одеська область дуже багата на різні водойми та з огляду на відповідність природно-кліматичних умов території всі вони придатні для вирощування риби.

Виробництво товарної риби на базі ставкових господарств різного иільового призначення є перспективним напрямом у рибництві. Значення його в агропромисловому секторі країни невпинно зростає. Сучасне рибництво на більшості малих водойм не враховує продуктивних можливостей иих водойм. Розрив між можливою та фактичною величинами рибопродуктивності досить великий $і$ досягає одного-двох порядків, що свідчить про значні резерви, раціональне використання яких дасть змогу підвищити ефективність рибництва. При ц̧ьому головний приріст продукиї можна отримувати завдяки оптимізаиії використання природних кормових ресурсів, тобто застосування пасовищної аквакультури.

Важко переоцінити значення природної кормової бази для аквакультури. У водоймах комплексного призначення це необхідна частина раціону риб, яка значною мірою визначає успіх рибництва.

Природна кормова база ставів включає комплекс гідробіонтів, які використовуються для живлення безпосередньо або через проміжні харчові ланки і визначає приріст рибної продукиії.

При цььому природну кормову базу розділяють на потенційну, яка включає весь комплекс гідробіонтів, чзо населяють ту чи іншу водойму, і реальну, тобто ту частину потениійної кормової бази, яка споживається в їюу певним видом риб на такій віковій стадії. 
Мета роботи полягала у з'ясуванні рибопродуктивності рибного господарства «Яски» з метою створення спеиіального товарного рибного господарства.

У иій роботі доведена можливість ефективного ведення рибного господарства, отримання товарної рибної продукиії та ї̈ подальшої реалізації населенню у рибному господарстві «Яски» та надані рекомендації щзодо створення спеціалізованого товарного рибного господарства.

Ключові слова: рибне господарство, ставки, рибопродуктивність, кормова база, рибництво, іхтіофауна.

Formulation of the problem. The fund of inland water bodies of the Odessa region is quite significant and in terms of the natural and climatic conditions meets the requirements to provide the conditions for fish production throughout the region.

Commercial fish production on the basis of the pond farms of different purposes is a promising area in fisheries. Its value in the agricultural sector of the country is increasing steadily. Modern fisheries in the most small water bodies do not take into account the productive capabilities of these bodies. The gap between the possible and actual fish productivity magnitudes is large enough and reaches one or two orders of magnitude, indicating significant reserves which rational using will improve the efficiency of fisheries. In this case the main increase in production can be obtained by optimizing the use of natural feed resources, i.e. using grazing aquaculture $[1 ; 2]$.

Therefore, it became necessary to generalize and analyze data on determining the productive capacity of ponds on the example of the ponds in the Yaski fisheries, to determine a volume of fishing and a forecast of fish catching for the future, as well as the creation of a special commercial fishery.

Analysis of recent research and publications. A number of special commercial fisheries operate in the Odessa region. Such entities include full-scale commodity fisheries, hatcheries and fish farm reclamation stations [3-4].

The current state of the feed base development indicates the possibility of successful fishing activities and in particular the development of special commercial fisheries.

Setting a task. The purpose of the work was to find out the fish productivity of the Yaski fishery in order to create a special commercial fishery.

To achieve this goal the following tasks were set:

1) to analyze the production capacity of the fishery ponds;

2) to investigate a size-weight and age structure of the main industrial fish population;

3) to explore the possibility of creating a special commercial fishery based on fisheries.

Outlining the main research material. The Yaski fishery started its activity more than 20 years ago. It renews aquatic living resources, grows carp fish, white and mottled silver carp, white carp, catfish for their further fishing in the Turunchuk. For the future economic development "Yaski" plans to increase the number of native species artificial reproduction and to introduce polyculture for the purpose of commercial fish production.

The Yaski fishery includes two ponds (for cultivation and for wintering). A cultivation pond is 6.0 ha, a wintering pond is 0.5 ha. The range of seasonal fluctuations of the depths can exceed $2.5-4.0 \mathrm{~m}$. The ponds are filled by rain and melt water, as well as by groundwater. It largely forms the hydrological and hydrochemical regime of the ponds (Table 1).

One of the important hydrophysical indicators is the transparency of water, which reflects the qualitative status of the aquatic ecosystem, the intensity of the planktonic communities development. The color of the water is greenish-brown. The depth of the photic layer, within which phytoplankton vegetation and zooplankton vital activity occur, is $0.2 \mathrm{~m} \mathrm{[5-9].}$ 
Table 1

Basic hydrological and hydrochemical characteristics of the Montenegrin pond water

\begin{tabular}{|c|l|c|c|c|}
\hline № & \multicolumn{1}{|c|}{ Indexes } & unit of measurement & MAC & Pond \\
\hline 1 & $\mathrm{pH}$ active reaction & & $6,5-8,5$ & $7,5-8,3$ \\
\hline 2 & Mineralization & $\mathrm{g} / \mathrm{l}$ & 1,0 & 0,315 \\
\hline 3 & $\begin{array}{l}\text { The content of } \\
\text { dissolved oxygen }\end{array}$ & $\mathrm{mg} / \mathrm{l}$ & $\begin{array}{c}\text { No less } \\
4,0\end{array}$ & $7,5-9,7$ \\
\hline 4 & Transparency & $\mathrm{m}$ & 0,4 & $0,2-0,4$ \\
\hline 5 & BPK & $\mathrm{mg} \mathrm{O} / 1$ & 3,0 & 1,4 \\
\hline 6 & Nitrites & $\mathrm{mg} / 1$ & 0,08 & 0,08 \\
\hline 7 & Nitrates & $\mathrm{mg} / 1$ & 40,0 & 27,8 \\
\hline 8 & Ammonium nitrogen & $\mathrm{mg} / 1$ & 0,5 & 0,29 \\
\hline 9 & Phosphates & $\mathrm{mg} / 1$ & 0,2 & 0,16 \\
\hline 10 & Temperature & ${ }^{\circ} \mathrm{C}$ & & $4-28$ \\
\hline 11 & Color & & & greenish-brown \\
\hline
\end{tabular}

Dissolved gases, primarily oxygen, play a leading role in the formation of the abiotic component and the functioning of the biotic component of the hydro-ecosystem. Special observations on the dynamics of dissolved oxygen in the ponds have made it possible to establish that its concentrations provide a relatively favorable gas regime for hydrobionts.

There is no smell of hydrogen sulfide in the water. In terms of mineralization the water in the pond does not exceed the MAC and is quite suitable for cultivation freshwater fish and crustaceans.

The objective information regarding the development of the main groups of the natural feed base and their production capabilities make it possible to make a reliable forecast of potential fish productivity, which is the basis for determining the optimal variant of fishery exploitation of the studied ponds $[3 ; 6]$.

The calculation of the potential fish productivity of the water body by phytoplankton, zooplankton and zoobenthos showed that the ponds do not have an equal distribution of feed organisms, the overwhelming majority falls on phytoplankton and is $58 \%$.

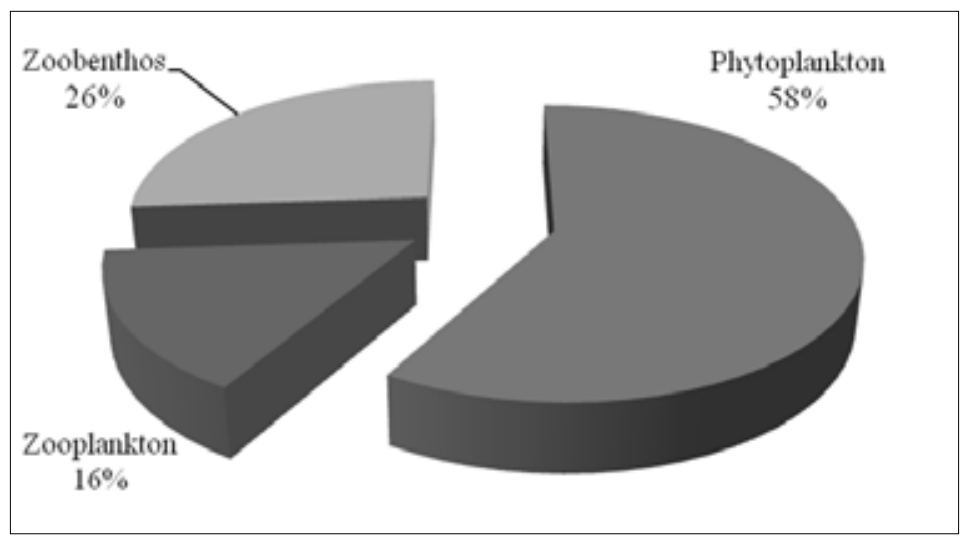

Fig. 1. Potential fish productivity of the ponds 
Now the ichthyocomplex of ponds is represented by carp, white and mottled silver carp, white carp, silver crucian and catfish (Table 2, Fig. 2).

Table 2

Characteristics of the main commercial fish species in the Yaski fishery

\begin{tabular}{|c|c|c|c|c|}
\hline View & Gender & Maturity & Age & Fatness \\
\hline Carp & Female & 3 & $3+$ & 1,7 \\
\hline Carp & Male & $3-4$ & $3+$ & 1,8 \\
\hline Silver carp white & Male & $2-3$ & $3+$ & 1,5 \\
\hline White Cupid & Male & $2-3$ & $2+$ & 1,2 \\
\hline Crucian & Female & 3 & $1+$ & 1,8 \\
\hline Crucian & Female & 3 & $2+$ & 2,0 \\
\hline Catfish & Male & 3 & $3+$ & 1,8 \\
\hline
\end{tabular}

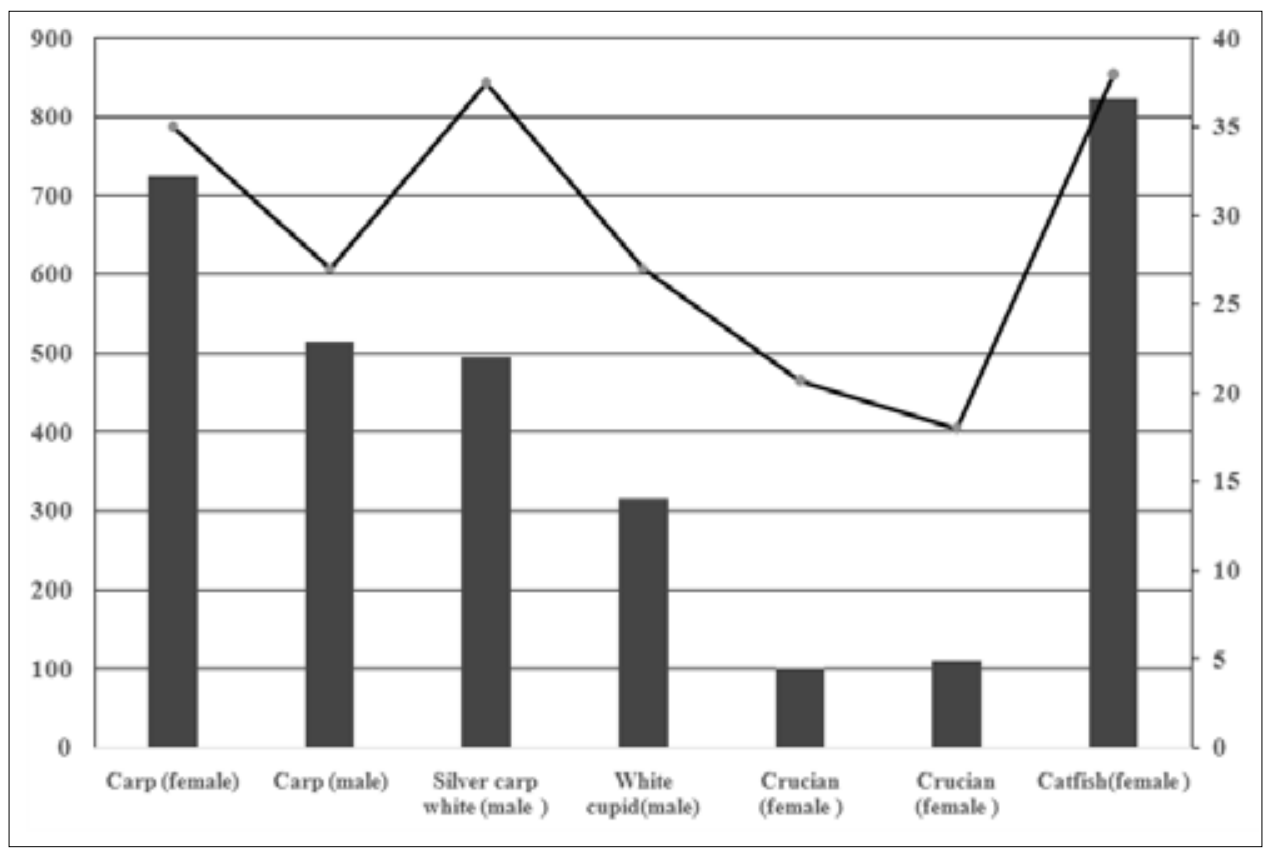

Fig. 2. Characteristics of the main commercial fish species in the Yaski fishery

The caught carps were characterized by sizes $35.0-27.0 \mathrm{~cm}$ with a mass of 725 and $515 \mathrm{~g}$, respectively. The white silver carp had a size of $37.5 \mathrm{~cm}$, and the white carp was $27 \mathrm{~cm}$, with a weight of 495 and $315 \mathrm{~g}$, respectively. The dimensions of the crucian carcass were $20.7-18.0 \mathrm{~cm}$, a weight was $102-110 \mathrm{~g}$. Catfish had a size of $38 \mathrm{~cm}$, a weight was $824 \mathrm{~g}$. The gonads of the studied specimens were at 2-3, 3, or 3-4 stages of maturity. The fat content of the analyzed fish was not very high, which could indicate the poor feed availability.

As a result of irrational economic activity in the previous period the valuable representatives of ichthyofauna are few in number.

Special Commodity Fisheries (SCFs) are organized for the purpose of artificial breeding and cultivation of the aquatic living resources and their using in the fishery 
water bodies. Such farms are created in coordination with the fishery protection authorities. These water bodies are managed in accordance with Article 8 of the Water Code of Ukraine [7].

The use of special fisheries (SF) is established by the territorial fishery protection authority in the area where its activities will be carried out. Beneficiaries (founders) of SF may be physical or legal persons of all forms of ownership.

The Yaski fishery ponds have been leased to the Bilyaiv district state administration for fish farming purposes.

The profitability assessment of the "tourist component" is rather complicated and poorly predicted. Considering the proximity to the settlements, the Odessa-Bilyaevka highway and the enough attractive surrounding landscape the ponds of the Yaski fishery can be a profitable business component when providing a certain range of services.

The ponds and the area around them should be aesthetically appealing for leisure and sport fishing. A high planting density of commercial fish species in the water body should ensure guaranteed fishing for holidaymakers. In addition to traditional fisheries it is advisable to use exotic carp species (colored, high-altitude, etc.) and other attractive for fishing species including predatory fish. It is possible to create a service for cooking meat and seafood dishes in particular from the caught by the amateur fishermen fish. "Democratic" and "elite" variants of the development of this project are possible.

Analyzing the experience of managing such facilities it can be expected that the visit intensity (depending on the range of offered services and the period of the year) will average at least 100 visits per month during the warm period of the year ( 6 months).

Recommendations for artificial fishing of cultural fishery.

Cultural fishery is planned to be established on the basis of the Yaski fishery.

The purpose of creating the cultural fishery on the indicated water body is the organization of paid amateur fishing. Thus the formation of the ichthyprice will be carried out by targeted fish stocking the pond with valuable fish species suitable as the objects of amateur and sport fishing. The farm ponds in this case are used as feeding. The farm has a wintering pond, the depths of which allow to leave the released fish for wintering.

According to the current standards the stocking volumes for this fishery will be:

- in the first year -6.8 thousand anniversaries $(0.204 \mathrm{t})$;

- from the second year -2.0 thousand biennials $(1.0 \mathrm{t})$.

In the future the scheme of fish stocking will be adjusted depending on the intensity of fish increasing, the percentage of their extraction and the degree of the development of the water body natural feed resources.

Such volumes of stocking are recommended for cultivation on the natural feed. Considering that during intensive amateur fishing the fish will be withdrawn within one year (mostly from spring to autumn), the number of fish can be increased 1.5-2 times.

With artificial feeding, according to the standards, the volume of stocking can be increased 3 times.

The volumes of fish extraction (by the species) should be recorded during amateur fishing. Based on these data the additional stocking is conducted. Thus a flock of different age fish species is formed in the ponds.

If artificial feed is used the density of fish stocking may be significantly increased. Feeding the fish the level of using feed should be monitored in the places specially designated for fish feeding. Feed places should be limed at least once a month.

Conclusions and suggestions. The studies conducted in the Yaski fishery revealed that the quality of the water, the state of the fish feed base and the ichthyofauna allow 
to grow commercial carp fish products in it that meets fishery and sanitary-hygiene requirements.

In order to maintain the quality of the aquatic environment in the farm, it is necessary to use herbivorous fish (white carp and hybrid forms of silver carp) with high growth rate and a resistance to high temperatures. That kind of fish is a biomeliorator.

As the fishery has a wintering pond with depths of up to $4.0 \mathrm{~m}$ the fish can be left for wintering. At high residual fish density in autumn, it is possible to conduct a partial rounding of the pond with the further realization of the caught fish. In this case spring stocking of the water bodies should be carried out taking into account the autumn extraction.

In the Yaski fishery a special commercial fishery is necessary to create for efficient fishery management, obtaining commercial fishery products and its further sale to the population.

\section{REFERENCES:}

1. Шерман И.М. Рыбоводство на малых водохранилищах. Москва :Агропромиздат, $1988.56 \mathrm{c.}$

2. Пилипенко Ю.В. Екологія малих водосховищ. Херсон : ОлдиПлюс, 2007. $351 \mathrm{c}$.

3. Бургаз M.І. Оцінка рибопродуктивності Чорногірського ставка з метою створення спеціального товарного рибного господарства. Таврійський науковий вісник. В 96, Херсон. 2016.

4. Шерман I.M., Краснощок Г.П., Пилипенко Ю.В. Рибництво. Київ : Урожай, 1992. 192 с.

5. Fishbase website, 2006. URL: www.fishbase.org.

6. Гринжевський М.В., Третяк О.М., Климов С.I. та ін. Нетрадиційні об'єкти рибництва в аквакультурі України. Київ : Світ, 2001. 164 с.

7. Загальнодержавна програма розвитку рибного господарства України: Затверджена Законом України від 19.02.2004 № 1516-IV. 